\title{
PENGARUH LINGKUNGAN KERJA, STRES KERJA DAN KOMPENSASI TERHADAP LOYALITAS KARYAWAN
}

\author{
I Wayan Sentana Putra ${ }^{1}$ \\ Anak Agung Ayu Sriathi ${ }^{2}$ \\ ${ }^{1,2}$ Fakultas Ekonomi dan Bisnis Universitas Udayana (Unud), Bali, Indonesia \\ E-mail: putras3ntana@gmail.com
}

\begin{abstract}
ABSTRAK
Tujuan penelitian ini adalah pengaruh lingkungan kerja, stres kerja dan kompensasi terhadap loyalitas karyawan. Penelitian ini dilakukan pada seluruh karyawan yang bekerja di Inna Bali Heritage Hotel. Populasi dari penelitian ini adalah 70 orang karyawan, dan sampel dalam penelitian ini menggunakan teknik metode sensus. Sampel penelitian ini berjumlah 70 orang karyawan hotel Inna Bali Heritage Hotel. Alat analisis yang digunakan adalah analisis regresi linier berganda. Hasil penelitian ini adalah terdapat pengaruh positif dan signifikan antara lingkungan kerja dan kompensasi terhadap loyalitas karyawan pada Inna Bali Heritage Hotel dan terdapat pengaruh negatif dan signifikan antara stress kerja terhadap loyalitas karyawan pada Inna Bali Heritage Hotel. Hasil penelitian ini memiliki teoritis dan praktis. Secara teoritis, hasil penelitian menunjukkan bahwa lingkungan kerja dan kompensasi berpengaruh positif dan signifikan terhadap loyalitas karyawan. Pemimpin hendaknya memperhatikan stres kerja yang dialami oleh karyawannya. Hal ini perlu diperhatikan yaitu perbedaan antara nilai - nilai dari perusahaan dan karyawan harus dapat dibijaksanakan oleh pihak manajemen.
\end{abstract}

Kata Kunci: lingkungan kerja, stres kerja, kompensasi, loyalitas

\begin{abstract}
The purpose of this study is the influence of work environment, job stress and compensation for employee loyalty. This research was conducted on all employees working at Inna Bali Heritage Hotel. The population of this research is 70 employees, and the sample in this study using census method technique. The sample of this study amounted to 70 employees.analysis data in this result used by multiple analysis regression. The result of this research is there is positive and significant influence between work environment and compensation to employee loyalty and there is negative and significant influence between work stress on employee loyalty at Inna Bali Heritage Hotel. The results of this study have theoretical and practical. Theoretically, the results showed that the work environment and compensation have a positive and significant impact on employee loyalty. Practically the results of this research is expected to provide benefits for leaders and employees of Hotel Inna Bali Heritage.
\end{abstract}

Keywords: work environment, job stress, compensation, loyalty 


\section{PENDAHULUAN}

Bali merupakan salah satu daerah tujuan wisata utama di Indonesia yang telah mendapat perhatian dari pemerintah dalam pariwisatanya. Pariwisata adalah aktivitas perjalanan yang dilakukan oleh sementara waktu dari tempat tinggal semula ke daerah tujuan dengan alasan bukan untuk menetap atau mencari nafkah melainkan hanya untuk memenuhi rasa ingin tahu, menghabiskan waktu senggang atau libur serta tujuan-tujuan lainnya. (Brian, 2016).

Dengan beragam tujuan wisata di Bali, muncul sarana pendukung dari industri pariwisata, contohnya hotel, restoran, spa, penyewaan kendaraan, jasa perjalanan wisata, wahana air, diskotik dan sebagainya. Namun dari seluruh sarana pendukung utama bisnis pariwisata terutama di Bali, adalah industri perhotelan. Mohajerani (2012:1) menyatakan "Industri hotel adalah salah satufaktor utama dari industri pariwisata. Hotel menunjang kegiatan utama dari industri pariwisata". Dalam arti luas, hotel mungkin merujuk pada segala jenis penginapan. Sedangkan dalam arti sempit, hotel adalah sebuah bangunan yang dibangun khusus untuk menyediakan penginapan bagi para pejalan, dengan pelayanan makanan dan minuman (Sihite,2016:31).

Secara garis besar penggolongan hotel berdasarkan lokasi, terdapat dua jenis hotel yaitu city hotel yang terletak di pusat kota, dan resort hotel yang terletak di suatu daerah tertentu yang lebih mengedepankan pemandangan dan suasana yang nyaman (Sihite,2016:13). Pada masa dewasa ini, persaingan di dunia perhotelan berada pada tahap yang sangat kompetitif. Di Bali sektor pariwisata terutama perhotelan menyumbang Gross Domestic Product (GDP) paling tinggi berkisar 84 
persen pada tahun 2015 (Sihite, 2016:21). Oleh karena itu, peningkatan kualitas dari pelayanan dan memaksimalkan setiap operasional hotel adalah hal yang krusial dilakukan agar sebuah hotel dapat bertahan dalam persaingan.

Dalam perkembangan global saat ini, persoalan tenaga kerja bagi negara maju maupun negara yang sedang berkembang seperti Indonesia cukup menarik perhatian untuk dikaji. Hal itu didasarkan asumsi bahwa tenaga kerja adalah modal dasar dalam proses pembangunan yang menempati posisi paling strategis, sebab sebagai tenaga kerja adalah sumber daya perusahaan yang perlu diperhatikan dalam perkembangan suatu perusahaan. Tenaga kerja yang berhubungan kerja dengan perusahaan, mempunyai peran yang sangat penting bagi kemajuan perusahaan. Dengan demikian, sewajarnyalah apabila kepada mereka diberikan perlindungan, pemeliharaan, dan pengembangan terhadap kesejahteraannya.

Menurut Mary (2016:71) perihal tenaga kerja, perusahaan sebaiknya menjadikan tenaga kerja sebagai salah satu fokus pengembangan dari strategi perusahaan. Hal tersebut dikarenakan perusahaan yang akan berkembang adalah perusahaan yang dapat memaksimalkan potensi tenaga kerjanya. Mary (2016:83) juga menjelaskan bahwa pentingnya loyalitas tenaga kerja karena jika pekerja sudah loyal terhadap perusahaan, maka operasional perusahaan akan lebih stabil. Jika loyalitas pekerja di perusahaan rendah, maka akan banyak pekerja yang mengundurkan diri sehingga kegiatan operasional pekerja menjadi terhambat. Karyawan yang baru direkrut juga perlu dilatih agar dapat menyesuiakan kondisi kerja yang baru, sehingga loyalitas perusahaan akan berkurang. Adekunle (2014) Pentingnya loyalitas karyawan bagi perusahaan adalah mempermudah operasional 
perusahaan dengan meminimalisir ongkos perekrutan baru bila banyak karyawan yang mengundurkan diri akibat kurang loyal kepada perusahaan. Berdasarkan data loyalitas karyawan diInna Bali Heritage Hotel, terdapat berkisar10 persen setiap pengunduran diri setiap tahunnya. Berikut data mengenai karyawan yang mengundurkan diri di Inna Bali Heritage Hotel.

Tabel 1.

Turnover Karyawan Inna Bali Heritage Hotel

\begin{tabular}{|c|c|c|c|c|}
\hline No & Bulan & $\begin{array}{c}\text { Jumlah } \\
\text { Karyawan }\end{array}$ & Karyawan Resign & $\begin{array}{l}\text { Persentase } \\
\text { Perputaran }\end{array}$ \\
\hline 1 & Januari & 70 & 6 & $9 \%$ \\
\hline 2 & Februari & 70 & 7 & $10 \%$ \\
\hline 3 & Maret & 70 & 10 & $14 \%$ \\
\hline 4 & April & 70 & 8 & $11 \%$ \\
\hline 5 & Mei & 70 & 7 & $10 \%$ \\
\hline 6 & Juni & 70 & 7 & $10 \%$ \\
\hline 7 & Juli & 70 & 9 & $13 \%$ \\
\hline 8 & Agustus & 70 & 4 & $6 \%$ \\
\hline 9 & September & 70 & 3 & $4 \%$ \\
\hline 10 & Oktober & 70 & 9 & $13 \%$ \\
\hline 11 & November & 70 & 11 & $16 \%$ \\
\hline \multirow[t]{3}{*}{12} & Desember & 70 & 6 & $9 \%$ \\
\hline & Jumlah & 840 & 87 & \\
\hline & Rata-rata & 70 & 7,25 & $10 \%$ \\
\hline
\end{tabular}

Sumber: Inna Hotel Heritage, 2017

Berdasarkan Tabel 1 diatas, dapat dilihat bahwa pada tahun 2017, total terdapat karaywan yang mengundurkan diri pada Inna Bali Heritage Hotel sebesar 87 kali karyawan mengundurkan diri. Persentase karyawan yang mengundurkan diri dapat mengukur loyalitas karyawan. Rata - rata karyawan yang mengundurkan diri berkisar 10 persen. Alasan dari pengunduran diri karyawan beragam, mulai dari lingkungan kerja yang kurang kondusif, stress kerja yang kurang sesuai dengan kompensasi yang diberikan.

Salah satu cara meningkatkan loyalitas kerja adalah dengan meningkatkan kualitas dari lingkungan kerja karyawan. Lingkungan kerja dapat mempengaruhi 
loyalitas tenaga kerja karyawan, dimana secara tersirat jika lingkungan kerja dari tenaga kerja tersebut baik, maka tenaga kerja tersebut akan lebih nyaman bekerja dan menghasilkan loyalitas yang lebih baik. Untuk menciptakan lingkungan kerja yang kondusif, terutama pada perusahaan hotel bintang tiga seperti Inna Bali Heritage Hotel, diperlukan beberapa usaha nyata untuk mewujudkannya. Hal tersebut merupakan salah satu komponen penting dalam proses untuk meningkatkan kepuasan tamu, mengingat dalam perusahaan jasa seperti hotel, produk utamanya adalah bersifat jasa yang mengutamakan pengalaman dari konsumen. Perusahaan dalam hal ini hotel Inna Bali Heritage Hotel harus mampu memberikan motivasi kepada para karyawannya agar karyawan terdorong untuk melaksanakan tugasnya dan dapat meningkatkan loyalitas perusahaan secara menyeluruh.

Lingkungan kerja dari Inna Bali Heritage Hotel sebenarnya sudah cukup kondusif untuk kegiatan operasional, namun terdapat masalah dari bangunan dan peralatan yang sudah sangat tua dan kurang terawat. Hal tersebut menyebabkan masalah di operasional yang mengakibatkan terdapat beberapa karyawan merasa tidak dapat bekerja secara maksimal dan akhirnya memutuskan untuk mengundurkan diri dari Inna Bali Heritage Hotel. Fenomena tersebut sering disebut dengan isu lingkungan kerja yang kurang kondusif (Yuliati, 2016).

Selain lingkungan kerja, mental dari para tenaga kerja juga perlu diperhatikan oleh perusahaan. Menurut Mangkunegara (2012), stres yang berlebihan dari para tenaga kerja akan membuat situasi dan lingkungan kerja dari suatu perusahaan akan menjadi lebih buruk. Hal tersebut dikarenakan stres dari karyawan akan dapat mempengaruhi emosi karyawan tersebut, dan emosi dari 
karyawan tersebut dalam memicu kesalahan dalam bekerja seperti pertengkaran dengan rekan kerja atau ketidak hati-hatian dari pekerja dalam melaksanakan tugasnya.

Selain permasalahan dibidang lingkungan kerja dan tenaga kerja, terdapat permasalahan mengenai stres kerja di Inna Bali Heritage Hotel. Permasalahan tersebut diakibatkan oleh banyaknya pekerjaan yang harus dilakukan karyawan dalam waktu yang singkat di Inna Bali Heritage Hotel. Masalah itu disebabkan oleh jumlah pekerja yang lebih sedikit dibandingkan dengan jumlah kamar yang tersedia. Hal tersebut mengakibatkan banyak pekerja muda yang baru bergabung di Inna Bali Heritage Hotel merasa kurang cocok dengan tanggung jawab pekerjaan dan akhirnya mengajukan pengunduran diri.

Mengingat pentingnya peranan tingkat stres karyawan dalam hal peningkatan loyalitas kerja karyawan, manajer perusahaan harus secara sungguhsungguh memperhatikan lingkungan kerja dan stres kerja karyawan. Hal ini diharapkan dapat membentuk suatu pola hubungan baik antara para karyawan dan perusahaan dimana para karyawan akan berpikir bahwa perusahaan tempat dimana mereka bekerja bisa memahami serta mengetahui kebutuhan hidup yang menjadi pemicu mengapa mereka bekerja.

Selain lingkungan kerja dan manajemen stress kerja, faktor yang dapat meningkatkan loyalitas kerja adalah kompensasi kepada tenaga kerja atau karyawan. Berdasarkan penelitian oleh Fuanida (2016) menyatakan bahwa kompensasi akan berdampak pada kecukupan hidup dari karyawan. Kompensasi yang mencukupi bagi karyawan akan memberikan mereka semangat dalam bekerja. Selain kompensasi, manajemen stres kerja diperlukan juga untuk 
mendorong tenaga kerja agar mereka mempunyai loyalitas dan kegairahan kerja yang tinggi atau yang lebih giat bekerja untuk meningkatkan tujuan prestasi kerja dari tenaga kerja itu, sehingga tujuan perusahaan akan tercapai (Almigo, 2014). Pemberian kompensasi finansial baik berupa gaji pokok, tunjangan hingga bonus yang besarnya berkaitan dengan loyalitas karyawan (Ashita, 2015).

Berikut merupakan detail kompensasi finansial yang diberikan manajemen Inna Bali Heritage Hotel berdasarkan tahun 2017.

Tabel 2.

Kompensasi Finansial Karyawan Inna Bali Heritage Hotel

\begin{tabular}{clccccc}
\hline No & Bulan & $\begin{array}{c}\text { Jumlah } \\
\text { Karyawa } \\
\text { n }\end{array}$ & Total Gaji & $\begin{array}{c}\text { Tunjangan } \\
\text { Hari Raya }\end{array}$ & $\begin{array}{c}\text { Tunjangan } \\
\text { Makan }\end{array}$ & $\begin{array}{c}\text { Jumlah } \\
\text { Kompensasi } \\
\text { Finansial }\end{array}$ \\
\hline 1 & Januari & 70 & 280.500 .000 & - & 34.100 .000 & 314.600 .000 \\
2 & Februari & 70 & 280.500 .000 & - & 31.900 .000 & 312.400 .000 \\
3 & Maret & 70 & 280.500 .000 & 40.000 .000 & 34.100 .000 & 394.600 .000 \\
4 & April & 70 & 280.500 .000 & - & 33.000 .000 & 313.500 .000 \\
5 & Mei & 70 & 280.500 .000 & - & 34.100 .000 & 314.600 .000 \\
6 & Juni & 70 & 280.500 .000 & - & 33.000 .000 & 313.500 .000 \\
7 & Juli & 70 & 280.500 .000 & - & 34.100 .000 & 314.600 .000 \\
8 & Agustus & 70 & 280.500 .000 & - & 34.100 .000 & 314.600 .000 \\
9 & September & 70 & 280.500 .000 & 30.000 .000 & 33.000 .000 & 343.500 .000 \\
10 & Oktober & 70 & 280.500 .000 & - & 34.100 .000 & 314.600 .000 \\
11 & November & 70 & 280.500 .000 & - & 33.000 .000 & 313.500 .000 \\
12 & Desember & 70 & 280.500 .000 & - & 34.100 .000 & 314.600 .000 \\
& Jumlah & 840 & 3.366 .000 .000 & 70.000 .000 & 402.600 .000 & 3.878 .600 .000 \\
& Rata-rata & 70 & 4.007 .142$. & 1.000 .000 & 33.550 .000 & 4.617 .380 \\
\hline
\end{tabular}

Sumber: Inna Hotel Heritage, 2017

Berdasarkan Tabel 2 dapat dilihat bahwa untuk 70 orang karyawan termasuk tim manajemen, secara total selama perbulan Manajemen mengeluarkan dana sebesar Rp 3.366.000.000 setahun. Hal tersebut menunjukkan rata - rata pendapatan per orang di Inna Bali Heritage Hotel sebesar Rp 4.007.142 per bulan. Tunjangan hari raya diberikan sebesar Rp 1.000.000 per tahun untuk seluruh karyawan, sehingga dalam setahun manajemen mengalokasikan dana sebesar Rp 70.000.000 setahun. Total kompensasi yang diterima karyawan rata - rata 
sebesar Rp 4.617.000 perbulan dengan total alokasi dana dari manajemen sebesar Rp. 3.878.600.000.

Kompenasi yang diberikan selain gaji pokok adalah berupa penghargaan MyStarkepada karyawan yang mendapatkan nilai tertinggi berdasarkan loyalitas mereka. Karyawan yang menjadi MyStarmendapatkan voucher menginap gratis di hotel Inna rekanan lainnya, uang tunai hingga souvenir yang diberikan special dari manajemen dan serangkaian pemilik dari Inna Bali Heritage Hotel. Walaupun kompensasi yang diberikan oleh pihak manajemen Inna Bali Heritage Hotel sudah memadai untuk menjaga loyalitas karyawan, namun masih terdapat beberapa karyawan yang tetap mengajukan pengunduran diri.

Penelitian yang dilakukan oleh Almigo (2014) menyatakan hasil bahwa jika karyawan memiliki lingkungan kerja yang baik serta kompensasi yang sesuai dalam bekerja, maka loyalitas karyawan akan meningkat. Kondisi ideal dalam bekerja tersebut dicapai salah satunya dengan minimnya stres kerja yang dialami karyawan, jadi karyawan dapat dengan nyaman bekerja. Teori dari Brian (2016) menyatakan bahwa loyalitas karyawan akan menjadi salah satu faktor dalam kesuksesan perusahaan. Maka dari itu diperlukan perhatian dari pihak perusahaan untuk menjaga tingkat loyalitas karyawan agar kinerja perusahaan tetap pada kondisi prima.

Menurut Cheng (2013) salah satu sarana penting pada manajemen sumber daya manusia dalam sebuah organisasi adalah tercapainya loyalitas kerja para karyawan. Loyalitas kerja sebenarnya merupakan keadaan yang sifatnya objektif, dimana dapat dilihat hasil nyatanya selama terjadi aktifitas pekerjaan pada suatu perusahaan. 
Christanto (2014) menyatakan bahwa loyalitas adalah penggunaan sumber daya manusia, keterampilan, teknologi, dan manajemen agar karyawan dapat bekerja dengan maksimal kepada perusahaan. Fuanida (2016) menyatakan bahwa "Loyalitas kerja merupakan pencapaian pelaksanaan kegiatan/pekerjaan oleh seseorang atau karyawan untuk mencapai tujuan organisasi/perusahaan dalam periode waktu tertentu. Dalam hal kaitannya dengan peningkatan loyalitas kerja karyawan diperlukan adanya lingkungan kerja yang baik, disiplin kerja yang tinggi, dan motivasi yang dapat membangkitkan semangat karyawan dalam bekerja."

Chuanbao (2015) menyatakan bahwa "Loyalitas kerja adalah suatu ukuran dari pada hasil kerja atau loyalitas seseorang dengan proses input sebagai masukan dan output sebagai keluarannya yang merupakan indikator dariloyalitas karyawan dalam menentukan bagaimana usaha untuk mencapai loyalitas yang tinggi dalam suatu organisasi. "Campbell (2015) menyatakan bahwa loyalitas kerja adalah kemampuan seorang pekerja untuk mencapai target pekerjaannya dengan beberapa peralatan, teknologi dan prosedur yang telah disediakan. Berdasarkan beberapa pengertian tersebut dapat dikemukakan bahwa loyalitas adalah kesetiaan dan usaha maksimal dari karyawan dalam bekerja di suatu perusahaan.

Dunette (2016) menyatakan bahwa faktor - faktor yang memengaruhi loyalitas kerja dibagi menjadi dua kelompok yaitu faktor intrinsik dan faktor ekstrinsik. Faktor intrinsik merupakan faktor yang timbul dari dalam diri karyawan dan sudah dimiliki karyawan sejak mulai bekerja di tempat kerjaannya. Contoh faktor intrinsik dari loyalitas ameliputi usia, masa kerja, jenis kelamin, 
tingkat pendidikan, prestasi yang dimiliki, ras dan beberapa sifat kepribadian. Faktor ekstrinsik merupakan faktor yang menyangkut hal - hal atau sesuatu yang berasal dari luar diri karyawan seperti kondisi fisik lingkungan kerja, hubungan yang terjalin antar karyawan dan sistem penggajian. Contoh faktor ekstrinsik berupa berupa tantangan kerja, job stress, kesempatan berinteraksi sosial, job enrichment, identifikasi tugas, umpan balik tugas dan kecocokan tugas.

Indikator loyalitas menurut Nawawi (2013:101) adalah sebagai berikut: 1) Taat pada peraturan yaitu karyawan wajib mengikuti peraturan yang harus ditaati. 2) Memiliki tanggung jawab pada perusahaanyaitu tanggung jawab yang diberikan perusahaan. 3) Kemauan untuk bekerja sama yaitu kondisi dimana rekan kerja dapat bekerja sama dalam menyelesaikan pekerjaan. 4) Rasa memiliki terhadapkeberadaan perusahaan yaitu rasa memiliki karyawan terhadap segala keberadaan perkembangan yang terjadi di perusahaan. 5) Hubungan antar pribadi yang harmonis di perusahaan yaitu kondisi hubungan antar pekerja di perusahaan.

Fallon (2015), menyatakan bahwa lingkungan kerja merupakan segala sesuatu yang ada disekitar para pekerja yang dapat mempengaruhi dirinya dalam menjalankan tugas-tugas yang dibebankan, misalnya : kebersihan, keamanan dan lain-lain.Gehee(2015) menyatakan bahwa lingkungan kerja adalah kondisi tempat kerja erat kaitannya dengan lingkungan (kondisi penerangan, suara, udara dan sebagainya).Wijaya (2013) menyatakan bahwa lingkungan kerja merupakan area atau kondisi sekitar perusahaan yang dialami oleh karyawan selama melakukan proses bekerja.

Dari beberapa pernyataan diatas mengenai lingkungan kerja, dapat dikemukakan bahwa lingkungan kerja adalah suasana lingkungan tempat kerja 
dimana para karyawan melaksanakan pekerjaan sehari-hari. Dalam hal ini seperti keadaan penerangan atau cahaya di tempat, keadaan udara ditempat kerja, keadaan suara di tempat kerja serta keadaan perlengkapan kerja.

Berikut indikator lingkungan kerja bagi karyawan (Gordon, 2016) adalah 1) Pelayanan para tenaga kerja ini merupakan salah satu faktor yang penting untuk membentuk lingkungan kerja didalam perusahaan dengan pelayanan yang baik oleh perusahaan maka para tenaga kerja akan memperoleh kepuasan kerja. 2) Kondisi kerja merupakan kondisi dalam perusahaan dimana para tenaga kerja yang dapat dipersiapkan oleh manjemen perusahaan. Kondisi kerja yang tidak memadai akan menimbulkan penurunan produktifitas.

Indikator dari lingkungan kerja adalah sebagai beriku (Hatumale, 2014). 1) Penerangan. Maksud penerangan disini adalah bukan hanya listrik tetapi termasuk juga penerangan yang baik mempercepat proses produksi. Penerangan perlu untuk kesehatan, keamanan, dan daya guna para pekerja. Tanpa akan menyebabkan kerusakan pada mata, kecelakaan dan kerusakan bahan meningkat dan produksi akan mundur (Hwang, 2016). 2) Pertukaran udara. Pertukaran udara yang cukup terutama dalam tata ruang kerja sangat diperlukan bila dalam ruang tersebut penuh karyawan. Pertukaran udara yang cukup akan menjadikan kesegaran para karyawan. Sebaliknya pertukaran yang kurang akandapatmenimbulkan rasa pengap sehingga mudah menimbulkan kelelahan dari karyawan (Ibrahim, 2013). 3) Keamanan. Rasa aman menimbulkan ketenangan dan mendorong semangat kerja karyawan. Keamanan yang di maksud disini adalah keamanan dalam lingkungan kerja yang meliputi keamanan terhadap milik pribadi yang merupakan harta yang paling berharga. Tidak ada rasa aman terhadap rasa milik pribadi 
karyawan dapat menimbulkan kegelisahan pada waktu menjalankan tugas (Joanna, 2016) . Sehingga keadaan ini akan menyebabkan semangat dan kegairahan kerja menurut, konsentrasi menjadi buyar dan berakibat pada menurunnya loyalitas kerja karyawan. Sedangkan keamanan pribadi adalah keamanan terhadap keselamatan kerja bagi setiap karyawan dalam menjalankan tugasnya masing-masing. 3) Kebisingan. Kebisingan yang terus menerus akan dirasakan sebagai gangguan apalagi oleh pekerjaan-pekerjaan yang membutuhkan konsentrasi tinggi. Sebenarnya kebisingan yang terus menerus akan menimbulkan terganggunya kesehatan yang mengacaukan konsentrasi dalam bekerja (Kirutigha; 2015). 4) Temperatur. Dalam keadaan normal, tiap anggota tubuh manusia mempunyai temperatur berbeda. Tubuh manusia selalu berusaha untuk mempertahankan keadaan normal, dengan suatu sistem tubuh yang sempurna sehingga dapat menyesuaikan diri dengan perubahan yang terjadi di luar tubuh. Tetapi kemampuan untuk menyesuaikan diri tersebut ada batasannya, yaitu bahwa tubuh manusia masih dapat menyesuaikan dirinya dengan temperatur luar tubuh tidak lebih dari 20 persen untuk kondisi panas dan 35 persen untuk kondisi dingin dari keadaan normal tubuh.

Thomas (2012), mendefinisikan stres sebagai suatu tanggapan dalam menyesuaikan diri yang dipengaruhi oleh perbedaan individu dan proses psikologis, sebagai konsekuensi dari tindakan lingkungan, situasi atau peristiwa yang terlalu banyak mengadakan tuntutan psikologis dan fisik seseorang. Dengan demikian dapat disimpulkan bahwa stres kerja timbul karena tuntutan lingkungan dan tanggapan setiap individu dalam menghadapinya dapat berbeda-beda. 
Masalah stres kerja di dalam organisasi perusahaan menjadi gejala yang penting diamati sejak mulai timbulnya tuntutan untuk efisiensi di dalam pekerjaan. Stres kerja karyawan perlu dikelola oleh seorang pimpinan perusahaan agar potensi-potensi yang merugikan perusahaan dapat diatasi (Sahlan,2016).Akibat adanya stres kerja yaitu seseorang atau karyawan menjadi Nervous, merasakan kecemasan yang kronis, peningkatan ketegangan pada emosi, proses berpikir dan kondisi fisik individu. Menurut Schuler, stres adalah suatu kondisi dinamis dimana individu dihadapkan pada kesempatan, hambatan dan keinginan dan hasil yang diperoleh sangatlah penting tetapi tidak dapat dipastikan (Robbins, 2016).

Fathoni (2006:176) mengatakan bahwa terdapat enam faktor penyebab stres kerja karyawan dalam suatu organisasi, antara lain beban kerja yang sulit dan berlebihan, tekanan dan sikap pimpinan yang kurang adil dan tidak wajar, waktu kerja yang terbatas dan peralatan yang kurang, konflik antara pribadi dengan pimpinan atau kelompok kerja, balas jasa yang terlalu rendah dan adanya masalah-masalah keluarga.

Stres kerja yang dialami oleh karyawan dapat menimbulkan dampak positif, sekaligus dampak negatif bagi yang bersangkutan dan bagi organisasi atau perusahaan. Aspek positif dari stres kerja itu dapat ditemukan jika dilihat dari kegunaannya dan kesediaan kita dalam menggunakannya (Tjiabrata,2016). Dari beberapa penjelasan bahwa stres kerja dapat dikemukakan sebagai suatu keadaan tegang yang dialami seseorang didalam suatu organisasi. Stres ini dapat merupakan akibat dari lingkungan fisik, sistem dan teknik dalam organisasi, 
interaksi sosial interpersonal, struktur pekerjaan, tingkah laku sebagai anggota dan aspek-aspek organisasi lainnya (William, 2012).

Terdapat dua faktor penyebab atau sumber munculnya stres atau stres kerja, yaitu faktor lingkungan kerja dan faktor personal. Faktor lingkungan kerja dapat berupa kondisi fisik, manajemen kantor maupun hubungan sosial di lingkungan pekerjaan. Sedang faktor personal bisa berupa tipe kepribadian, peristiwa atau pengalaman pribadi maupun kondisi sosial-ekonomi keluarga di mana pribadi berada dan mengembangkan diri, (Soepalarto, 2016).

Menurut Sulastiyono (2014) kondisi-kondisi yang menyebabkan stres disebut dengan istilah Stresors. Stres dapat disebabkan oleh Satu Stresor, biasanya karyawan mengalami stres karena kombinasi beberapa Stresor. Ada dua kategori penyebab stres, yaitu $O n-T h e-J o b$ dan Off-The-Job. Hampir dalam setiap kondisi pekerjaan di perusahaan dapat menyebabkan stres tergantung pada reaksi karyawan. Misalnya, seorang karyawan akan dengan mudah menerima dan mempelajari prosedur kerja baru, sedangkan seorang karyawan yang lain tidak atau bahkan menolaknya.

Beberapa indikator yang menyebabkan stres bagi karyawan dinyatakan sebagai penyebab stres kerja (Sulastiyono, 2014) antara lain. 1) Beban kerja yang berlebihan adalah beban kerja yang diberikan melebihi tanggung jawab. 2) Tekanan atau desakan waktu adalah rentang waktu yang diberikan perusahaan untuk menyelesaikan pekerjaan. 3) Umpan balik tentang pelaksanaan kerja yang tidak memadai adalah evaluasi pekerjaan yang diberikan perusahaan terhadap karyawannya. 4) Konflik antar pribadi dan antar kelompok adalah kondisi yang 
kurang kondusif dimana disebabkan perbedaan pandangan dari pribadi atau kelompok di tempat kerja. 5) Perbedaan antara nilai-nilai perusahaan dan karyawan adalah perbedaan cara pandang terhadap suatu nilai perusahaan oleh masing - masing individu di perusahaan tersebut.

Kryukova (2014 : 46) menyatakan bahwa, kompensasi karyawan adalah semua bentuk pembayaran atau hadiah yang diberikan kepada karyawan dan muncul dari pekerjaan mereka. Pada dasarnya terdapat dua cara untuk membuat pembayaran keuangan kepada karyawan, yaitu pembayaran langsung dan pembayaran tidak langsung (Yaseen,2016). Pembayaran langsung adalah pembayaran dalam bentuk upah, gaji, insentif, komisi dan bonus.Sedangkan pembayaran tidak langsung adalah pembayaran dalam bentuk tunjangantunjangan keuangan seperti asuaransi.

Kunartinah (2016:4) menyatakan bahwa kompensasi (compensation) meliputi imbalan finansial dan jasa serta tunjangan yang diterima oleh para karyawan sebagai bagian dari hubungan kekaryawanan. Kompensasi merupakan apa yang diterima oleh para karyawan sebagai ganti kontribusi mereka kepada organisasi (Anas,2014)

Terminologi kompensasi sering digunakan secara bergantian dengan administrasi gaji dan upah; kendatipun demikian, terminologi kompensasi sesungguhnya merupakan konsep yang lebih luas (Khan,2015).Manakala dikelola secara benar, kompensasi membantu organisasi mencapai tujuannya dan memperoleh, memelihara, dan mempertahankan tenaga kerja yang produktif. 
Malayu Lan Xia (2014:118) menyatakan bahwa kompensasi adalah semua pendapatan yang berbentuk uang atau barang langsung maupun tidak langsung yang diterima karyawan sebagai imbalan atas jasa yang telah diberikan kepada perusahaan.Sedangkan Mangkuprawira (2012:14) menyatakan bahwakompensasi adalah total seluruh imbalan yang di terima para karyawan sebagai pengganti jasa yang telah mereka berikan.Salinding (2014:156) menyatakan bahwa kompensasi dapat berupa tunjangan yang merupakan sebuah penghargaan tidak langsung yang diberikan untuk seorang karyawan. Berdasarkan beberapa pengertian tersebut dapat dikemukakan bahwa kompensasi adalah imbalan balas jasa kepada karyawan atas segala pekerjaan yang dilakukan oleh karyawan tersebut.

Pada dasarnya kompensasi dapat dikelompokkan ke dalam dua kelompok, yaitu kompensasi finansial dan kompensasi bukan finansial.Selanjutnya kompensasi finansial ada yang langsung dan ada yang tidaklangsung. Sedangkan kompensasi nonfinansial dapat berupa pekerjaan dan lingkungan pekerjaan Mangkuprawira (2012). 1) Kompensasi finansial yang dinyatakan oleh Neeraj (2014:46) adalah kompensasi dari loyalitas karyawan yang diberikan berupa uang. Kompensasi finansial yang diberikan secara langsung, yaitu gaji, upah, komisikomisi dan bonus. Dan yang kedua adalah kompensasi finansial yang diberikan secara tidak langsung, seperti tunjangan kesehatan, tunjangan pensiun, tunjangan hari raya, tunjangan pendidikan, tunjangan perumahan dan lain sebagainya. 2) Omotayo (2015:35) menyatakan bahwa kompensasi non finansial adalah kepuasan yang diterima seseorang dari pekerjaan itu sendiri atau dari lingkungan psikologis dan atau fisik tempat orang tersebut bekerja. Selanjutnya kompensasi non finansial dibagi menjadi dua macam yaitu yang berhubungan dengan 
pekerjaan dan yang berhubungan dengan lingkungan kerja. Yang berhubungan dengan pekerjaan misalnya saja kebijakan perusahaan yang sehat, pekerjaan yang sesuai, menarik dan menantang, peluang untuk dipromosikan, pemberian jabatan sebagai symbol status, sedangkan untuk kompensasi non finansial yang berhubungan dengan lingkungan kerja seperti ditempatkan di lingkungan kerja yang kondusif, lingkungan kerja yang sehat, aman dan nyaman, fasilitas kerja yang baik dan memadai dan lain-lainnya. Adapun Prabu (2016:420) mengemukakan jenis kompensasi dapat berupa penghargaan intrinsik dan ekstrinsik.

Penghargaan intrinsik sering meliputi pujian atas penyelesaian sebuah proyek atau pemenuhan tujuan loyalitas. Pengaruh psikologis dan sosial yang lain mencerminkan penghargaan intrinsik. Sedangkan penghargaan ekstrinsik adalah penghargaan yang nyata dan berupa penghargaan moneter dan nonmoneter Robbins (2016:29)

Lingkungan kerja memiliki pengaruh positif terhadap loyalitas karyawan. Hal tersebut disebabkan dengan lingkungan kerja yang nyaman akan membuat pekerja menjadi semangat dalam melakukan pekerjaannya sehari hari. Kenyamanan dalam bekerja sehari - hari akan membuat pekerja enggan untuk berpindah pekerjaan dan memilih loyal untuk bekerja di suatu organisasi atau perusahaan.

Penelitian oleh Rafdan (2016) yang berjudul "Analisis Pengaruh Lingkungan kerja Kompensasi Serta Kompetensi Terhadap Loyalitas Karyawan (Studi pada PT Pos Semarang)", menyatakan bahwa terdapat pengaruh signifikan antara lingkungan kerja terhadap loyalitas karyawan. Hal tersebut senada dengan 
penelitian yang dilakukan oleh, AdekunleAdetola (2014), Fallon, Edwar (2015), GeheeSinea (2015), Hwang Xi (2016) yang menyatakan bahwa lingkungan kerja berpengaruh positif terhadap loyalitas karyawan.

Selain berdasarkan teori dari Andrews (2013) menyatakan bahwa lingkungan kerja yang baik akan menimbulkan kenyamanan dalam melakukan kegiatan kerja sehari-hari. Pada dasarnya pekerja menghabiskan waktu yang cukup lama di lingkungan kerja, dimana hal tersebut menyebabkan jika terdapat sesuatu yang salah pada lingkungan kerja akan berdampak pada kondisi emosi dari para pekerja. Maka dari itu hipotesis pertama dari penelitian ini adalah:

$\mathrm{H}_{1}$ : $\quad$ Lingkungan kerja berpengaruh positif dan signifikan terhadap loyalitas

Stres kerja berpengaruh negatif terhadap loyalitas karyawan. Hal tersebut disebabkan dengan tingginya tingkat stres kerja akan membuat karyawan tidak betah dalam melaksanakan pekerjaannya sehari - hari. Jika karyawan tidak nyaman bekerja maka karyawan memiliki kecenderungan untuk melakukan pergantian pekerjaan demi mencari tempat bekerja yang dapat membuat karyawan nyaman bekerja.

Penelitian oleh DjatmikoNoviantoro pada tahun 2016 yang berjudul “Analisis Pengaruh Lingkungan kerja Dan Stres Kerja Terhadap Loyalitas Karyawan Pada PT. Perusahaan Perkebunan Sumatra Indonesia Tbk Medan", menyatakan bahwa terdapat pengaruh signifikan antara stres kerja terhadap loyalitas karyawan. Hal tersebut senada dengan penelitian yang dilakukan oleh Brian Anthony (2016), Ibrahim Mahamid (2013), Kirutigha (2015), 
ManulangVivi (2012) dan Michael Timothy (2016) yang menyatakan bahwa stres kerja berpengaruh negatif terhadap loyalitas karyawan.

Berdasarkan teori dari Gehee (2012) menyatakan bahwa masalah stres kerja di dalam organisasi perusahaan menjadi gejala yang penting diamati sejak mulai timbulnya tuntutan untuk efisiensi di dalam pekerjaan. Perusahaan harus memperhatikan stres kerja karyawannya, karena karyawan merupakan aset berharga bagi perusahaan yang merupakan faktor penting untuk mencapai tujuan suatu organisasi. Jika stres kerja karyawan tinggi, maka dikhawatirkan kinerja karyawan akan menurun. Maka dari itu hipotesis kedua dari penelitian ini adalah:

$\mathrm{H}_{2}$ : Stres kerja berpengaruh negatif dan signifikan terhadap loyalitas karyawan.

Kompensasi berpengaruh positif terhadap loyalitas karyawan. Hal tersebut disebabkan dengan tingginya tingkat kompensasi akan membuat karyawan merasa dihargai pekerjaannya. Jika karyawan merasa dihargai selama bekerja maka karyawan memiliki kecenderungan untuk tetap setia pada perusahaan karena kebutuhan utama akan pekerjaan yaitu penghidupan secara motif ekonomi dapat dipenuhi perusahaan.

Penelitian oleh Wendy Wijayapada tahun 2013 yang berjudul "Analisis Lingkungan kerja dan Kompensasi Terhadap Loyalitas Karyawan Pada Pabrik Kecap Wie Sin di Lombok", menyatakan bahwa terdapat pengaruh signifikan antara kompensasi terhadap loyalitas karyawan. Hal tersebut senada dengan penelitian yang dilakukan oleh Cheng Siew Yee (2013), OmotayoOsibanjo 
(2013), Neeraj (2014), Robbins (2016) yang menyatakan bahwa kompensasi berpengaruh positif terhadap loyalitas karyawan.

Berdasarkan teori dari Mangkuprawira (2012) menjelaskan bahwa kompensasi yang sesuai akan menimbulkan kenyamanan bekerja dari para karyawan. Kenyamanan dalam bekerja akan menimbulkan loyalitas bekerja, Maka dari itu hipotesis ketiga dari penelitian ini adalah:

$\mathrm{H}_{3}$ : Kompensasi berpengaruh positif dan signifikan terhadap loyalitas karyawan.

\section{METODE PENELITIAN}

Lokasi pada penelitian ini adalah Inna Bali Heritage Hotel yang terletak di Jalan Veteran no 2 - Denpasar. Letaknya sangat strategis dan dekat dengan Puri Denpasar, Museum Bali, dan beberapa objek wisata internasional yang terkenal. Alasan pemilihan Inna Bali Heritage Hotel sebagai lokasi penelitian adalah karena hotel ini adalah salah satu hotel di Denpasar yang menjadi pionir hotel mewah, dimana memiliki jumlah karyawan berskala besar dengan manajemen sumber daya yang sudah terorganisir.

Ruang lingkup penelitian ini adalah loyalitas karyawan, yang meliputi seluruh karyawan di Inna Bali Heritage Hotel di masing-masing department. Terdapat 6 departemen di Inna Bali Heritage Hotel, yaitu Housekeeping, Engineering, Front Office, Sales \& Marketing, Accounting dan Food and Beverages. 
Variabel Independen di dalam penelitian ini adalah variabel lingkungan kerja (X1), stres kerja (X2) dan kompensasi (X3). Variabel dependen di dalam penelitian ini adalah loyalitas karyawan (Y).

Populasi dalam penelitian ini adalah seluruh karyawan di hotel Inna Bali Heritage Hotel sebanyak 70 orang karyawan. Teknik pengumpulan sampel pada penelitian ini adalah metode sensus. Metode sensus adalah pengambilan sampel yang merupakan berasal semua anggota dalam populasi. Sampel dalam penelitian ini adalah 70 orang karyawan di Inna Bali Heritage Hotel sebagai responden dalam penyebaran kuesioner.

Dalam penelitian ini, digunakan analisa regresi linear berganda. Analisis regresi linear merupakan metode statistik yang paling jamak dipergunakan dalam penelitian-penelitian sosial, terutama penelitian ekonomi. Program komputer yang paling banyak digunakan adalah SPSS (Statistical Package For Service Solutions.

\section{HASIL PENELITIAN DAN PEMBAHASAN}

Berdasarkan kuisioner yang diberikan kepada 70 sampel, berikut merupakan deskripsi jawaban dari responden berdasarkan setiap item pertanyaan yang terlampir di kuisioner. Variabel loyalitas kerja secara keseluruhan memiliki ratarata 4,46 yang berarti loyalitas kerja yang dialami karyawan sangat baik. Hal ini berarti secara keseluruhan responden setuju bahwa loyalitas kerja di perusahaan sudah sangat baik. Skor terendah adalah 4,08 yang terletak pada pernyataan "Saya memiliki tanggung jawab sebagai pekerja pada perusahaan”.

Variabel lingkugan kerja secara keseluruhan memiliki rata-rata 4,46 yang berarti lingkungan kerja yang dialami karyawan sangat baik. Hal ini berarti 
secara keseluruhan responden setuju bahwa lingkungan kerja di perusahaan sudah sangat baik. Skor terendah adalah 4,20 yang terletak pada pernyataan "Keamanan di tempat kerja saya baik"

Variabel stres kerja secara keseluruhan memiliki rata-rata 1,56 yang berarti stresskerja yang dialami karyawan sangat rendah. Hal ini berarti secara keseluruhan responden setuju bahwa stress di perusahaan sudah sangat rendah. Skor terendah adalah 1,16 yang terletak pada pernyataan "Perbedaan antara nilainilai perusahaan dengan karyawan dapat dibijaksanakan oleh manajemen”.

Variabel kompensasi secara keseluruhan memiliki rata-rata 4,46 yang berarti kompensasi yang dialami karyawan sangat baik. Hal ini berarti secara keseluruhan responden setuju bahwa kompensasi di perusahaan sudah sangat baik. Skor terendah adalah 4,53 yang terletak pada pernyataan "Upah yang diberikan sudah sesuai dengan tugas karyawan".

Tabel 3.

Hasil Analisa Linear Berganda

\begin{tabular}{|c|c|c|c|c|c|c|}
\hline & \multirow{2}{*}{ Model } & \multicolumn{2}{|c|}{$\begin{array}{l}\text { Unstandardized } \\
\text { Coefficients }\end{array}$} & \multicolumn{3}{|c|}{ Standardized Coefficients } \\
\hline & & B & Std. Error & Beta & $\mathbf{t}$ & Sig. \\
\hline \multirow[t]{4}{*}{1} & (Constant) & 4.980 & .977 & & 5.098 & .000 \\
\hline & $\mathrm{X} 1$ & .537 & .570 & .660 & 2.916 & .003 \\
\hline & $\mathrm{X} 2$ & -.681 & .519 & -.719 & -1.682 & .002 \\
\hline & $\mathrm{X} 3$ & .652 & .533 & .672 & 1.568 & .003 \\
\hline
\end{tabular}

Berdasarkan Tabel 3 diatas diperoleh persamaan sebagai berikut:

$$
\begin{aligned}
& \mathrm{Y}=\mathrm{a}+\mathrm{B}_{1} \cdot \mathrm{X}_{1}+\mathrm{B}_{2} \cdot \mathrm{X}_{2}+\mathrm{B}_{3} \cdot \mathrm{X}_{3} \\
& Y=4.98+\left(0,537 X_{1}\right)-(0,681 X 2)+(0,652 X 3)
\end{aligned}
$$

Persamaan regresi tersebut dapat dijelaskan bahwa nilai koefisien regresi lingkungan kerja $(\mathrm{X} 1)=0,537$ artinya apabila lingkungan kerja meningkat 
sedangkan stres kerja dan kompensasi tetap, maka lingkungan kerja berpengaruh kepada nilai loyalitas karyawan (Y) sebesar 0,537.

Nilai koefisien regresi stres kerja $(\mathrm{X} 2)=-0,681$ artinya apabila stres kerja meningkat sedangkan lingkungan kerja dan kompensasi tetap, maka stres kerja berpengaruh kepada nilai loyalitas karyawan (Y) sebesar 0,68.

Nilai koefisien regresi kompensasi $(\mathrm{X} 3)=0,652$ artinya apabila kompensasi meningkat sedangkan lingkungan kerja dan stres kerja tetap, maka kompensasi berpengaruh kepada nilai loyalitas karyawan (Y) sebesar 0,652 .

Berdasarkan penjelasan variabel lingkungan kerja menunjukkan rata - rata nilai skor melalui lima butir pernyataan 4,71. Hasil nilai pengujian tersebut memperoleh, dapat dilihat dengan statistik bahwa uji jatuh pada penolakan $\mathrm{H}_{0}$ ditolak dan $\mathrm{H}_{1}$ diterima untuk hipotesis pertama. Hal tersebut menyatakan penerimaan hipotesis yang bahwa terdapat pengaruh positif dan signifikan antara Lingkungan Kerja terhadap Loyalitas karyawan pada Inna Bali Heritage Hotel.

Hal penelitian ini mendukung penelitian olehRafdan Rahinnaya (2016), Adekunle Adetola (2014), Fallon, Edwar (2015), GeheeSinea (2015), Hwang Xi (2016) yang memperoleh bahwa terdapat pengaruh positif dan signifikan antara Lingkungan Kerja terhadap Loyalitas karyawan pada Inna Bali Heritage Hotel. Lingkungan kerja adalah suasana lingkungan tempat kerja dimana para karyawan melaksanakan pekerjaan sehari-hari. Sehingga semakin baik lingkungan kerja karyawan, semakin tinggi loyalitas karyawan.

Berdasarkan penjelasan variabel stress kerja memperoleh rata - rata nilai skor melalui lima butir pernyataan 1,80. Berdasarkan nilai pengujian tersebut, 
dapat dilihat dengan statistik bahwa uji jatuh pada penolakan $\mathrm{H}_{0}$ ditolak dan $\mathrm{H}_{3}$ diterima untuk hipotesis kedua. Hal tersebut menyatakan penerimaan hipotesis yang bahwa terdapat pengaruh negatif dan signifikan antara Stres Kerja terhadap Loyalitas karyawan pada Inna Bali Heritage Hotel Denpasar.

Hal penelitian ini mendukung penelitian oleh Djatmiko Noviantoro (2016), Brian Anthony (2016), Ibrahim Mahamid (2013), Kirutigha (2015), ManulangVivi (2012), Michael Timothy (2016) yang memperoleh bahwa terdapat pengaruh negatif dan signifikan antara Stres Kerja terhadap Loyalitas karyawan. Stres kerja adalah suatu keadaan tegang yang dialami seseorang didalam suatu organisasi. Stres ini dapat merupakan akibat dari lingkungan fisik, sistem dan teknik dalam organisasi, interaksi sosial interpersonal, struktur pekerjaan, tingkah laku sebagai anggota dan aspek-aspek organisasi lainnya. Sehingga semakin tinggi stress kerja karyawan, semakin rendah loyalitas karyawan.

Berdasarkan penjelasan variabel kompensasi memperoleh rata - rata nilai skor melalui empat butir pernyataan 4,80. Hasil nilai pengujian tersebut memperoleh, dapat dilihat dengan statistik bahwa uji jatuh pada penolakan $\mathrm{H}_{0}$ ditolak dan $\mathrm{H}_{1}$ diterima untuk hipotesis pertama. Hal tersebut menyatakan penerimaan hipotesis yang bahwa terdapat pengaruh positif dan signifikan antara Lingkungan Kerja terhadap Loyalitas karyawan pada Inna Bali Heritage Hotel .

Hal penelitian ini mendukung penelitian oleh Wendy Wijaya (2013), Cheng Siew Yee (2013), Omotayo Osibanjo (2013), Neeraj (2014), Robbins (2016) yang menyatakan bahwa terdapat pengaruh positif dan signifikan antara lingkungan kerja terhadap loyalitas karyawan. Kompensasi adalah imbalan balas jasa kepada 
karyawan atas segala pekerjaan yang dilakukan oleh karyawan tersebut. Sehingga semakin baik kompensasi yang diterima karyawan, semakin tinggi loyalitas karyawan.

Koefisien determinasi dalam regresi linear adalah sebagai besar kemampuan variabel bebas dalam menjelaskan variansnya. Koefisien determinasi menggunakan metode $R$ square,

Tabel 4.

Hasil Uji Determinasi

\begin{tabular}{lcccc}
\hline Model & R & R Square & $\begin{array}{c}\text { Adjusted R } \\
\text { Square }\end{array}$ & Std. Error of the Estimate \\
\hline 1 & $.667^{\mathrm{a}}$ & .646 & .610 & .231 \\
\hline Sumber: Data diolah, 2018 & &
\end{tabular}

Sesuai hasil perhitungan regresi linear berganda diperoleh nilai koefisien korelasi $\left(\mathrm{R}^{2}\right)$ sebesar 0,646 hal ini menunjukkan bahwa adanya hubungan positif yang sangat kuat antarasebesar dengan kontribusi sebesar 64.6persen dari Loyalitas Karyawan (Y) dipengaruhi oleh Lingkungan Kerja (X1) Stres Kerja (X2) dan Kompensasi (X3) Sedangkan sisa sejumlah 35.4persen dipengaruhi oleh faktor lain yang tidak diteliti dalam penelitian ini.

Hasil penelitian ini memiliki implikasi teoritis dan praktis. Secara teoritis, hasil penelitian menunjukkan bahwa lingkungan kerja, stress kerja dan kompensasi berpengaruh positif dan signifikan terhadap loyalitas karyawan. Dengan demikian hasil penelitian ini memberi dukungan empiris dan dinyatakan dapat memperkuat hasil - hasil studi terdahulu. Secara praktis hasil penelitian in diharapkan dapat memberikan manfaat bagi para pemimpin serta karyawan Hotel Inna Bali Heritage. Manajemen diharapkan dapat menyesuaikan lingkungan kerja agar lebih kondusif dan dapat membuat nyaman para pekerja yang bergabung 
sehingga dapat meningkatkan loyalitas kerja dari karyawan. Selain itu manajemen juga harus memperhatikan stress kerja dan kompensasi kerja yang diberikan agar kompensasi dan stress kerja yang diberikan dapat lebih merata sesuai dengan keinginan bersama.

\section{SIMPULAN DAN SARAN}

Berdasarkan hasil penelitian, maka dapat disimpulkan bahwa lingkungan kerja berpengaruh positif dan signifikan terhadap loyalitas karyawan pada Inna Bali Heritage Hotel. Hal ini menunjukkan bahwa semakin baik kualitas lingkungan kerja karyawan, maka semakin baik loyalitas bekerja dari karyawan tersebut. Stres kerja berpengaruh negaitf dan signifikan terhadap loyalitas karyawan pada Inna Bali Heritage Hotel. Hal ini menunjukkan bahwa semakin tinggi tingkat stres kerja karyawan, maka semakin rendah loyalitas bekerja dari karyawan tersebut. Kompensasi berpengaruh positif dan signifikan terhadap loyalitas karyawan pada Inna Bali Heritage Hotel. Hal ini menunjukkan bahwa semakin baik kompensasi yang diterima karyawan, maka semakin baik loyalitas bekerja dari karyawan tersebut.

Berdasarkan keterbatasan yang terdapat dalam penelitian ini, maka penelti mengajukan kepada Pemimpin hendaknya memperhatikan stres kerja yang dialami oleh karyawannya. Hal ini perlu diperhatikan yaitu perbedaan antara nilainilai dari perusahaan dan karyawan harus dapat dibijaksanakan oleh pihak manajemen.Pemimpin hendaknya memperhatikan lingkunan kerja yang diberikan kepada karyawannya. Hal ini perlu diperhatikan pimpinan perusahaan karena lingkungan kerja yang baik akan meningkatkan loyalitas karyawan pada Hotel Inna Bali Heritage. 


\section{REFERENSI}

Adekunle, Adetola. (2014). Impact of Online Employee Training on Operational Risk Management. Journal of The Business School University of Gloucestershire. 14(1):113-225.

Almigo, Nuzsep. (2014). Hubungan Antara Kepuasan Kerja Dengan Loyalitas Karyawan. Jurnal Ekonomi dan Bisnis. 12(5):145-187.

Andrews, Greg. (2013). The System to Maintain Employee Productivity with Training. PT. Balai Pustaka : Jakarta.

Ashita, Sharma. (2015). A Review Study On The Information Technology Applications In Hotel Industry. Journal of Economic Studi, India. 22(2):110.

Anas,Khaidir. (2014).Pengaruh Kompensasi dan Lingkungan Kerja Terhadap Kepuasan Kerja Karyawan PT.Karya Mitra Muda Abadi. Jurnal Bisnis dan Ekonomi. 9(4):138-163

Brian, Anthony. (2016). Development of Tourism Object in South East Asia. PT. Gramedia. Jakarta

Campbell, Kelley. (2015). Flexible Work Schedules, Virtual Work Programs, and Employee Productivity. Journal of Walden Dissertations and Doctoral Studies. 19(7):172-194.

Cheng Siew Yee, Gee Oon Kei, Law VoonEe, Ng Sze Wee and Tai MunYing .(2013). The Effect Of Training And Development Provided By Organization Towards Employee Productivity In Hotel Industry. A research project of Bachelor Of Business Administration. 23(4):890-914.

Christanto, Freddie Yeremia dan Santoso, Thomas. (2014). Analisis Lingkungan kerja Dan Pengembangan Sumber Daya Manusia Di PT. Wahana Kosmetika Indonesia. JurnalProgram Manajemen Bisnis Universitas Petra. 5(1): 73-79.

Chuanbao Yu, Haiyan Sun and Baozhen Han. (2015). Design and Implementation of Chinese High Star-Level Hotel Management Information System. International Conference on Education Technology, Management and Humanities Science. 1(7):130-150.

Fuanida, Afni. (2016). Pengaruh Kompensasi, Stres Kerja, Dan Motivasi Terhadap Loyalitas Kerja Karyawan CV. Sapu Dunia Semarang. Jurnal Ilmu Administrasi Bisnis. 4(6):128-211.

Gehee, Sinea. (2015). The Best Way to Train The New Employee. PT. Java Books : Jakarta. 
Hwang, Xi.(2016). Development of Hotel Management To Survive on Today Business. CV. TintaBhuana:Yogjakarta.

Ibrahim Mahamid, A. Al-Ghonamy and M. Aichouni. (2013). Major Factors Influencing Employee Productivity in the KSA Public Construction Projects. International Journal of Civil \& Environmental Engineering IJCEE-IJENS, Vol.14(1):1-25.

Kirutigha. (2015). Greeting and Service at Hotel Industry. PT. Bhuana Ilmu Populer : Jakarta.

Kryukova, Elena Mikhaylovna and Sokolova, Antonina Pavlovna. (2014). Assessment of Efficiency of the Hotel Management by a Russian Company. World Applied Sciences Journal 30 (Management, Economics, Technology \& Tourism).17(8):46-82.

Kunartinah. (2016). Pengaruh Pendidikan Dan Lingkungan kerja, Pembelajaran Organisasi Terhadap Kinerja Dengan Kompetensi Sebagai Mediasi. Jurnal Bisnis dan Ekonomi. 8(3):4-72

Khan,W.E. Dan Mutfi,O.(2015).Effect of Compensation on Motivating EmPLOYEES In Public and Private Bank Of Peshawer (BOK and UBL).Journal of Basic And Applied Scientific Research.9(4):58-120.

Malayu Lan Xia and Juan Wang. (2014). Analysis on Policy Support System of Substituted Post Exercitation Based on Hotel Management Major. Journal of International Conference on Science and Social Research. 3(5):132-162.

Mangkuprawira, Muhammad. (2012). Lingkungan kerja dan Pengembangan Karakter Para Karyawan. PT. Grasindo : Jakarta.

Mary, Muller. (2016). Impact of Employee Training and Motivation on Business Development in Banking Sector: Study Conducted in Pakistan. American Journal of Business, Economics and Management. 7(9):145-230.

Manulang, Vivi. (2012). Pentingnya Pemilihan Karyawan Pada Dampaknya Dengan Kinerja Perusahaan. PT. Gramedia : Jakarta.

Michael, Timothy. (2016). Hotel Industry On The $21^{\text {st }}$ Universe. PT. The Critique : Jakarta.

Mohajerani, Pardis. (2012). Customer Satisfaction Modeling in Hotel Industry, A Case Study of Kish Island in Iran. International Journal of Marketing Studies. 19(6):173-242.

Neeraj. (2014) . A case study approach for evaluation of Employee Training Effectiveness and Development program. Journal of Proceedings the 
Second International Conference on Global Business, Economics, Finance and Social Sciences (GB14 Conference).15(3):46-189.

OmotayoOsibanjo, Adewale, Gberevbie Daniel Eseme, Adeniji Anthonia Adenike and Oludayo Akinrole Olumuyiwa. (2015). Relationship Modeling between Work Environment, Employee Productivity, and Supervision in the Nigerian Public Sector. Journal of Business and Administration. 11(3):140213.

Robbins. (2016).Skill and Attitude To Attract The Company Interest While Job Seeking. PT. Absolut Media : Jakarta.

Salinding,Rony.(2014).Pengaruh Lingkungan kerja Terhadap Loyalitas Kerja Karyawan Pada PT.Erajaya Swasembada Cabang Bandung.Jurnal Ekonomi dan Bisnis.5(2):156-210.

Sharma, Ashita. (2015). A Review Study On The Information Technology Applications In Hotel Industry. Journal Of Business Policy \& Governance. 2(3):1-14.

Sihite. (2016). Operasional Hotel dan Pengembangannya. PT. Kompas : Jakarta.

Soepalarto, Ahmad. (2016). Konsep Pengembangan dan Lingkungan kerjadari Industri Pertanian Indonesia. PT. Gramedia : Jakarta.

Syafii,Mochamad, (2015).Pengaruh Lingkungan Kerja Dan Loyalitas Kerja Terhadap Kinerja Karyawan Di Perum Kesatuan Bsnis Mandiri Industri Kayu Gersik.Jurnal Program Manajemen Universitas Brawijajaya Malang.7(5):245-280

Sahlan,Nurul. (2016).Pengaruh Lingkungan Kerja,Stres Kerja,Dan Kompensasi Terhadap Kinerja Karyawan Pada PT. Bank SULUT Airmadidi.Jurnal Program Manajemen Universitas Brawijaya Malang.5(3): 112-152

Thomas, Dobbelstein and Carsten, Brehm. (2012). Perception Of Cost, Cost Drivers, Human Resource Management, Long And Short Term Critical Success Factors In The Hotel Industry: Recommendations For Hotel Management. African Journal of Business Management.3(8):273-298.

Tjiabrata,Reinhard,(2016).Pengaruh Stres Kerja Dan Lingkungan Kerja Terhadap Kinerja Karyawan PT.Sambar Abadi Ganda Manado.Jurnal Program Manajemen Universitas Sam Ratulangi Manado.3(2):139-181.

Wijaya, Wendy. (2013). Analisis Lingkungan kerja Dan Pengembangan Sumber Daya Manusia Pada Pabrik KecapWie Sin Di Lombok. Jurnal Program Manajemen Bisnis. 9(2):612-629.

William D. Frye. (2012). An Examination of Job Satisfaction of Hotel Front Office Managers According to Extrinsic, Intrinsic, and General 
E-Jurnal Manajemen, Vol. 8, No. 2, 2019: 7746 - 7774

Motivational Factors. International Journal of Business and Social Science. 2(5): 89-106.

Yuliati, Sri. (2016). Pengaruh Motivasi Dan Lingkungan kerja Terhadap Kinerja Karyawan Politeknik Pratama Mulia Surakarta. Jurnal POLITEKNOSAINS. 8(3):210-260.

Yeseen,A. (2016).Effect of Compensation Factors On Employee Satisfaction A Study Of Doctor Dissatifaction in punjad. Internatonal Journal of Human Resource Studies.6(5):149-268. 